\title{
Rapid diagnosis of respiratory syncytial virus infection in children by the immunofluorescent technique
}

\author{
J. E. CRADOCK-WATSON, JOYCE MCQUILLIN, AND P. S. GARDNER
}

From the Public Health Laboratory, Withington Hospital, Manchester, the Department of Virology, Universit of Newcastle, and the Royal Victoria Infirmary, Newcastle upon Tyne

SYNOPSIS The immunofluorescent examination of nasopharyngeal secretions has been compared with conventional cell culture for the diagnosis of respiratory syncytial (RS) virus infection in children under the age of 2 years in Newcastle upon Tyne and Manchester. Two hundred and sixty-eight identifications of RS virus were made by the fluorescent method, of which $258(96 \%)$ were confirmed culturally. In 267 children from whom virus was isolated in cell culture a positivez diagnosis was made by the fluorescent method in $258(97 \%)$. In 238 infants with bronchiolitis diagnosis of RS virus infection was made on the basis of the fluorescent test in $185(78 \%)$ of which $180(97 \%)$ were subsequently confirmed in cell culture. The reasons for false results are briefly discussed. It is concluded that the method is reliable for the early diagnosis of respiratory syncytiai virus infection.

Respiratory syncytial (RS) virus is now generally accepted as being the principal cause of severe lower respiratory tract infection in infants, particularly during the winter months. However, RS virus is slow to produce a cytopathic effect in cell culture and final identification by this means may take as long as 21 to 28 days. There is therefore a need for a more rapid method of diagnosis as an aid to the management of children suffering from infection with this agent. Joncas, Berthiaume, Williams, Beaudry, and Pavilanis (1969) have detected 'RS-like structures' in nasopharyngeal secretions examined directly by electron microscopy, but these particles may be difficult to distinguish from other paramyxoviruslike particles; moreover the method is limited by the availability of the equipment.

More rapid identification of the virus in cell culture can be obtained by the immunofluorescent staining of cells detached from culture tubes. Using an indirect fluorescent antibody technique McQuillin and Gardner (1968) applied this method to cultures inoculated with material from 16 children suffering from bronchiolitis. They obtained, correctly, a positive result in eight cases, had only one failure and no 'false positives'. This method still took from two to seven days. These workers showed, however, that the fluorescent antibody technique could be used as Received for publication 16 September 1970. a reliable substitute for the neutralization test in virus identification.

Attention has therefore been turned to immuno fluorescent staining of material obtained directlys from patients. Smears from throat swabs were examined by the indirect fluorescent antibody technique by Gray, MacFarlane, and Sommerville (1968), but although this method was successful in many cases, these workers found that $14 \%$ of their positive immunofluorescent results could not be confirmed in cell culture. McQuillin and Gardner (1968) found this method unsatisfactory because of non-specific fluorescence of background debris and because the preparations did not contain sufficient. intact cells. McQuillin, Gardner, and Sturdy (1970) showed that intact cells eluted from cough swabs could be stained successfully by the immunoo fluorescent technique and suggested that this method might be useful in older children and in those na民 admitted to hospital.

In children under the age of 2 years more satis factory results have been obtained by the immuno? fluorescent examination of material aspirated from the nasopharynx. This approach was employed if Newcastle upon Tyne by Gardner and McQuillirg (1968) during the winter of 1967-68. Out of 34 specimens of nasopharyngeal secretion examined by the indirect fluorescent antibody technique, 17 
showed fluorescence when tested with an anti-RS virus rabbit serum and an anti-rabbit conjugate. Respiratory syncytial virus was isolated in cell culture from all these 17 cases and from two others which showed no fluorescence. The remainder were negative, both by the fluorescent method and in cell culture, and in no case was the fluorescent test positive in the absence of subsequent isolation. Because the immunofluorescent examination of nasopharyngeal secretions seemed such a promising technique it was continued at the Royal Victoria Infirmary, Newcastle upon Tyne, and was brought into use at the Public Health Laboratory, Manchester, during the winters of 1968-69 and 1969-70. The results for the two years from both centres are presented in this communication in order to demonstrate the advantages of the method and to suggest the possibility of its application as a routine procedure in other virus laboratories.

The materials and methods used were in general similar to those previously described by McQuillin and Gardner (1968), Gardner and McQuillin (1968), and Sturdy, McQuillin, and Gardner (1969). Differences in the techniques used in Newcastle and Manchester are indicated where relevant.

\section{Patients}

Specimens were obtained from children under the age of 2 years admitted to hospital with acute respiratory infection, predominantly of the lower respiratory tract. In Newcastle the children were admitted to the Royal Victoria Infirmary, the General Hospital, and the Fleming Memorial Hospital. In Manchester all the children studied were admitted to the Duchess of York Hospital for Babies.

\section{COLLECTION OF SPECIMENS}

A throat swab and a specimen of nasopharyngeal secretion were collected from each patient at the same visit, as soon as possible after admission to hospital.

\section{Throat swabs}

Throat swabs were broken off into bijoux bottles of transport medium consisting of Hanks' lactalbumin solution with $0.2 \%(w / v)$ bovine albumin and antibiotics. The bottles were conveyed in ice to the laboratory where the medium was used to inoculate tubes of 'Bristol' HeLa, HEp2', secondary rhesus monkey kidney and WI38 cells. In Manchester during the second half of the survey cell cultures

${ }^{1}$ The line of HEp2 cells used in Manchester during the second half of the survey was obtained from Flow Laboratories Limited, Irvine, Ayrshire. were inoculated directly with a throat swab at the patient's bedside (Manchester Public Health Laboratory, 1964).

\section{Nasopharyngeal secretions}

Secretions were collected into plastic disposable mucus traps ${ }^{2}$. One arm of the trap was connected to a suction machine; the other arm was connected to a plastic feeding tube ${ }^{3}$ which was passed down each nostril in turn so that the tip of the tube reached the nasopharynx. With some babies one nostril only could be used because the other was already occupied by a tube inserted for feeding purposes. Nasopharyngeal secretions were sucked into the trap, which was then disconnected from the tubes, packed in ice and conveyed to the laboratory.

\section{Preparation of Nasopharyngeal Specimens for Immunofluorescence}

The lid of the mucus trap was removed in a dust-free manner by cutting through the upper part of the trap with a hot wire. Secretions were transferred from the trap to a bijou bottle containing $2 \mathrm{ml}$ of Dulbecco ' $A$ ' phosphate-buffered saline and suspended in the phosphate-buffered saline by sucking up and down with a wide-mouthed Pasteur pipette. Excessive vigour was avoided at this stage because the purpose of the procedure is to examine intact cells. After the suspension had been centrifuged at $1,000 \mathrm{rpm}$ for 10 minutes the supernatant was removed and used to inoculate cell cultures. The deposit was then suspended in $2 \mathrm{ml}$ of phosphatebuffered saline and centrifuged again. The resulting supernatant was discarded and the deposited cells were then resuspended in two or three drops of phosphate-buffered saline for making smears on slides. On each slide two smears, each approximately $1 \mathrm{~cm}$ square, were made, one for treatment with antiRS virus serum and the other for treatment with normal rabbit serum at the same dilution. The smears were allowed to dry in air and then fixed in acetone at $4^{\circ} \mathrm{C}$ for 10 minutes. Preparations must not be too thick, both because the stain may be unable to penetrate and because if the cells are too densely packed those which are fluorescent may be less easily identified.

IMMUNOFLUORESCENT STAINING PROCEDURE The same antisera were used at both centres. They were prepared and absorbed in the Newcastle laboratory by methods previously described. The

\footnotetext{
'Sterile mucus extractors, obtainable from Johnson \& Johnson Limited, Slough, Bucks.

${ }^{3}$ Bardic sterile feeding tubes size 8 Fr., obtainable from Bard-Davol Limited, Clacton-on-Sea, Essex.
} 


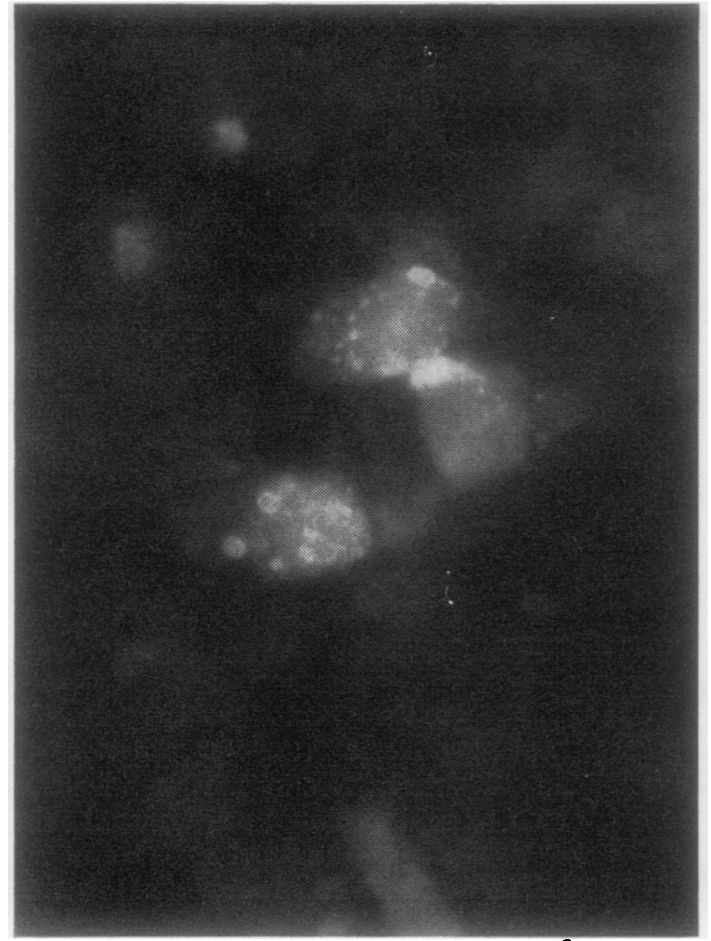

Fig. 1.

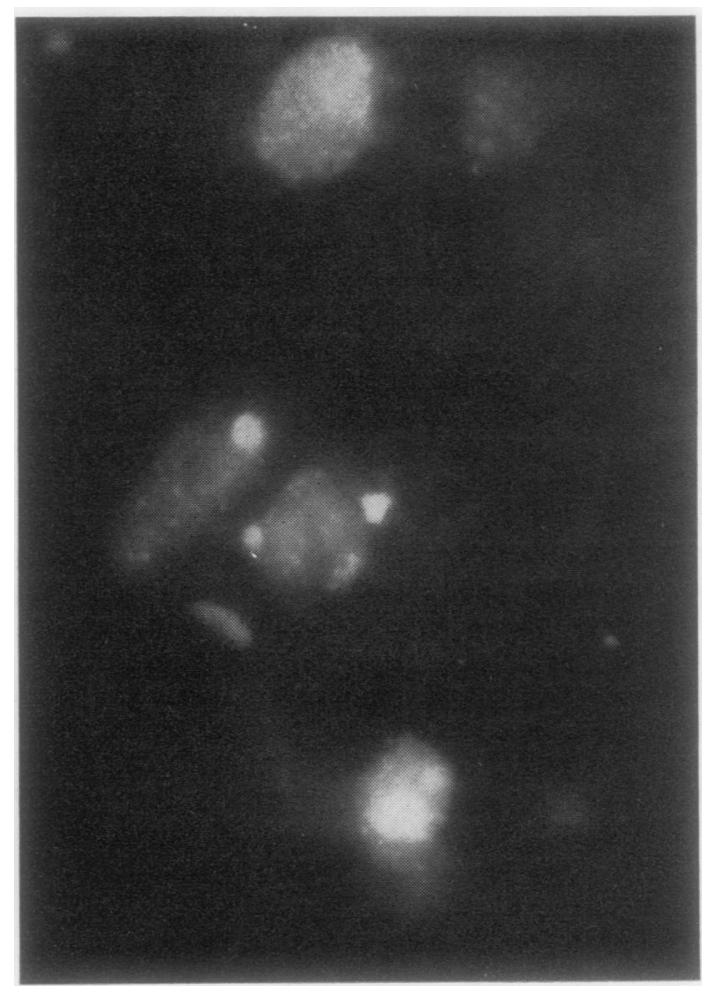

Fig. 2.

Figures 1 and 2 show fluorescent cytoplasmic particles in a number of cells from two nasopharyngeal secretions stained by the immunofluorescent technique for $R S$ virus (Fig. $1 \times 700$ ). Fig. $2 \times 850$ ).

conjugate used was Fluoroscan Plus supplied by Winthrop Biologicals Limited. No changes were introduced into the staining procedure.

\section{FLUORESCENT MICROSCOPY}

\section{Newcastle upon Tyne}

Specimens were examined under dark-ground illumination by blue light, using a Wild M.20 fluorescent microscope with an HBO 200 mercury vapour lamp, a blue BG 12/4 mm exciter filter, and an OG 1 barrier filter.

\section{Manchester}

Specimens were examined under dark-ground illumination by ultraviolet light, using a Reichert Zetopan microscope with an HBO 200 mercury vapour lamp, a UG $1 / 1.5 \mathrm{~mm}$ exciter filter and a GG 13/2 mm + Wratten 2B barrier filter. A toric lens glycerol-immersion condenser and a 60/0.95 glycerol-immersion objective fitted with an iris diaphragm have so far proved to be the most $\dot{0}$ suitable combination for examining this material. With this optical arrangement successful black and $\delta$ white photographs have been taken on Ilford HP4 $35 \mathrm{~mm}$ film with exposures ranging from 15 to 30 윽 seconds (Figs. 1 and 2).

In positive preparations a small proportion of $\frac{D}{2}$ cells shows intracellular fluorescent material. This material is cytoplasmic and takes the form of $s$ particles ranging from fine 'dust' to relatively large N round or oval bodies, giving the cell a speckled N appearance. The nucleus is unstained. Most pre- 0 parations contain at least one infected cell per microscopic field so that, when positive, a diagnosis can often confidently be made after the examination $\stackrel{\oplus}{\oplus}$ of only a few fields. Different areas of a specimen 0 may vary, however, and therefore several areas 0 should be examined. The appearances are character- $\stackrel{\mathbb{D}}{\circ}$ istic, and with experience a positive diagnosis can be $\mathbb{\mathbb { D }}$ made if only one or two fluorescent cells are found $\frac{2}{9}$ in a whole smear; consequently the whole area of a 


\begin{tabular}{|c|c|c|c|c|c|c|c|c|c|c|c|}
\hline \multirow{2}{*}{$\begin{array}{l}\text { Clinical } \\
\text { Category }\end{array}$} & \multirow{2}{*}{$\begin{array}{l}\text { No. in } \\
\text { Each } \\
\text { Clinical } \\
\text { Category }\end{array}$} & \multirow{2}{*}{$\begin{array}{l}\text { No. of } \\
\text { Isolations } \\
\text { of } R S \\
\text { Virus in } \\
\text { Cell } \\
\text { Culture }\end{array}$} & \multirow{2}{*}{$\begin{array}{l}\text { No. of } \\
\text { Identifi- } \\
\text { cations } \\
\text { of } R S \\
\text { virus by } \\
\text { Fluo- } \\
\text { rescence }\end{array}$} & \multirow{2}{*}{$\begin{array}{l}\text { FA- } \\
\text { negative } \\
\text { Isolation } \\
\text { Positive }\end{array}$} & \multirow{2}{*}{$\begin{array}{l}\text { FA- } \\
\text { positive, } \\
\text { Isolation } \\
\text { Negative }\end{array}$} & \multicolumn{5}{|c|}{ Other Viruses } & \multirow{2}{*}{$\begin{array}{l}\text { Percentage } \\
\text { of Cases } \\
\text { from which } \\
\text { RS Virus } \\
\text { was Iso- } \\
\text { lated or } \\
\text { Identified } \\
\text { by Fluo- } \\
\text { rescence }\end{array}$} \\
\hline & & & & & & $\begin{array}{l}\text { Adeno- } \\
\text { virus }\end{array}$ & $\begin{array}{l}\text { Para- } \\
\text { influenza } \\
\text { Virus }\end{array}$ & $\begin{array}{l}\text { Influenza } \\
\text { Virus }\end{array}$ & $\begin{array}{l}\text { Rhino- } \\
\text { virus }\end{array}$ & Echovirus & \\
\hline
\end{tabular}

\section{Upper}

respiratory

tract infection $\quad 32$

Croup 17

Bronchitis $\quad 62$

Bronchiolitis 200

Pneumonia $\quad 36$

Total

347

16
3
34
157
16
226

$\begin{array}{rl}18 & 1 \\ 3 & 0 \\ 36 & 0 \\ 159 & 1 \\ 16 & 0 \\ 232 & 2\end{array}$

3
$\mathbf{0}$
2
3
0
8

2
1
2
1
3
9

1
4
3
4
2
14

1
2
0
4
0
7

0
0
2
0
2
4

$\begin{array}{ll}0 & 59.5 \\ 1 & 17.5 \\ 0 & 58 \\ 2 & 80 \\ 0 & 44.5 \\ 3 & 67.5\end{array}$

Table I Examination of nasopharyngeal secretions for respiratory syncytial $(R S)$ virus by the fluorescent antibody (FA) technique compared with isolations in cell culture during the winters of 1968-69 and 1969-70 at the Royal Victoria Infirmary, Newcastle upon Tyne

\begin{tabular}{|c|c|c|c|c|c|c|c|c|c|}
\hline \multirow{2}{*}{$\begin{array}{l}\text { Clinical } \\
\text { Category }\end{array}$} & \multirow{2}{*}{$\begin{array}{l}\text { No. in Each } \\
\text { Clinical } \\
\text { Category }\end{array}$} & \multirow{2}{*}{$\begin{array}{l}\text { No. of } \\
\text { Isolations of } \\
\text { RS Virus in } \\
\text { Cell Culture }\end{array}$} & \multirow{2}{*}{$\begin{array}{l}\text { No. of } \\
\text { Identifications } \\
\text { of } R S \text { Virus } \\
\text { by Fluo- } \\
\text { rescence }\end{array}$} & \multirow{2}{*}{$\begin{array}{l}\text { FA-negative, } \\
\text { Isolation } \\
\text { Positive }\end{array}$} & \multirow{2}{*}{$\begin{array}{l}\text { FA-positive, } \\
\text { Isolation } \\
\text { Negative }\end{array}$} & \multicolumn{3}{|c|}{ Other Viruses } & \multirow{2}{*}{$\begin{array}{l}\text { Percentage of } \\
\text { Cases from } \\
\text { which RS Virus } \\
\text { was Isolated or } \\
\text { Identified by } \\
\text { Fluorescence }\end{array}$} \\
\hline & & & & & & Adenovirus & $\begin{array}{l}\text { Para- } \\
\text { influenza } \\
\text { Virus }\end{array}$ & $\begin{array}{l}\text { Cytomegalo- } \\
\text { virus }\end{array}$ & \\
\hline $\begin{array}{l}\text { Croup } \\
\text { Bronchitis } \\
\text { Bronchiolitis } \\
\text { Pneumonia }\end{array}$ & $\begin{array}{r}1 \\
17 \\
38 \\
7\end{array}$ & $\begin{array}{r}0 \\
8 \\
29 \\
4\end{array}$ & $\begin{array}{r}0 \\
8 \\
26 \\
2\end{array}$ & $\begin{array}{l}0 \\
0 \\
5 \\
2\end{array}$ & $\begin{array}{l}0 \\
0 \\
2^{1} \\
0\end{array}$ & $\begin{array}{l}1 \\
1\end{array}$ & 1 & 1 & $\begin{array}{r}0 \\
47 \\
82 \\
57\end{array}$ \\
\hline Total & 63 & 41 & 36 & 7 & 2 & 2 & 1 & 1 & 68 \\
\hline
\end{tabular}

Table II Examination of nasopharyngeal secretions for respiratory syncytial $(R S)$ virus by the fluorescent antibody (FA) technique compared with isolations in cell culture during the winters of 1968-69 and 1969-70 at the Public Health Laboratory, Manchester

${ }^{1}$ Adenovirus type 1 isolated from one case.

preparation should be examined before a negative result is declared. Figures 1 and 2 illustrate typical appearances in positive preparations.

\section{Results}

The results of immunofluorescence and cell culture from 347 children in Newcastle upon Tyne and 63 in Manchester are shown in Tables I and II respectively. Isolation in cell culture was made either from the nasopharyngeal secretion or the accompanying throat swab, or both.

If the results from both laboratories are combined a positive fluorescent test for RS virus was obtained in 268 cases and confirmed culturally in $258(96 \%)$ leaving 10 cases ('false positives') in which culture was negative. Nine of these 10 cases were children who had been ill for at least four days before specimens were taken. From the tenth child an adenovirus was isolated.

Out of 267 cases of RS virus infection from which the virus was isolated in cell culture a positive diagnosis was made by the fluorescent test in 258 $(97 \%)$, leaving nine cases ('false negatives') in which the fluorescent method failed to indicate the diagnosis. Five of the 'false negatives' in the Manchester laboratory occurred at the beginning of the investigation among the first seven specimens to yield virus in cell culture.

\section{Discussion}

Respiratory syncytial virus grows slowly in tissue culture and the immunofluorescent test described here confers a considerable saving in the time taken for diagnosis. For the test to be reliable two requirements are necessary. First, the material for fluorescent staining must contain intact cells because we have found that the essential criterion for positive diagnosis is the intracellular appearance of the fluorescent particles. Nasopharyngeal secretions are better material for this purpose than are throat swabs rolled on slides because they contain abundant intact cells, whereas the latter show relatively few 
such cells, many of which may be damaged. Intact cells can be eluted from cough swabs and used for immunofluorescent diagnosis but they are much less numerous than in nasopharyngeal secretions and finding them may require a prolonged search (McQuillin et al, 1970).

Secondly, the reagents must be potent, specific, and show no significant background fluorescence or staining of heterologous viral antigens. This may necessitate repeated absorption of the anti-RS virus serum with suspensions of HEp2 or HeLa cells. The serum must be screened against other viruses before it is put into use.

Our results show satisfactory correlation with established methods. If the results from the two laboratories are combined, out of 410 specimens 268 were positive by immunofluorescence, with only nine 'false negatives' and 10 'false positives'.

Provided that the reagents are satisfactory, 'false negatives' may be due to several factors: insufficient examination of the specimen, preparations which contain too few cells, or preparations which are too thick and mucoid so that infected cells can neither be stained effectively nor identified with certainty. Inexperience at the beginning of the investigation may also be a factor, as shown by the fact that five of the 'false negatives' in Manchester occurred among the first few specimens to be examined.

'False positives' may be due either to misleading non-specific fluorescence or to cultural failure in a positive case. Nine of the 10 children who provided 'false positive' preparations had been ill for at least four days; some had been ill for more than 14 days. Unpublished work in the Manchester laboratory has shown that the isolation rate from cases of RS virus infection falls markedly between the second and sixth days after admission to hospital. Antigen can be demonstrated by fluorescence longer than infection can be detected in cell culture (Gardner, McQuillin, and McGuckin, 1970) and it therefore seems likely that many of our 'false positives' were due to cultural failure in cases seen late in the course of the disease rather than to non-specific fluorescence. In one case a concurrent adenovirus infection could have interfered with the isolation of RS virus.

Although the fluorescent technique offers a clear advantage in terms of speed of diagnosis and may also be applicable when contamination makes tissue culture impossible, the method has some disadvantages. If the patients are any distance from the laboratory arrangements must be made to transport the specimens without delay, preferably cooled in ice, although the same requirement also applies to specimens for virus isolation if the best results are to be obtained. The technique is timeconsuming in terms of the relatively skilled work involved in collecting the specimens, making and staining the preparations, and finally examining them. Nevertheless we consider that the method is in potentially reliable and that accuracy could be $\vec{\circ}$ maintained and the disadvantages minimized by concentrating the tests from one urban area in one $\vec{\omega}$ laboratory. If the clinician is one who prefers to withhold antibiotics in RS virus infection then the advantages of rapid diagnosis certainly justify the time and work involved.

We thank Dr I). Macaulay and Dr G. V. Feldman for permission to study the patients in their care at the Duchess of York Hospital, Manchester. We also thank Professor S. D. M. Court and the medical staff of the Department of Child Health for access to their patients in the Newcastle hospitals. We are $\vec{v}$ grateful to the nursing staff at all the hospitals for their help in the collection of specimens, and to Dr J. O'H. Tobin of the Manchester Public Health Laboratory for his interest and encouragement in this work.

\section{References}

Gardner, P. S., and McQuillin, J. (1968). Application of immunofluorescent antibody technique in rapid diagnosis of respiratory syncytial virus infection. Brit. med. J., 3, 340-343.

Gardner, P. S., McQuillin, J., and McGuckin, R. (1970). The late detection of respiratory syncytial virus in cells of respiratory $\bar{O}$ tract by immunofluorescence. J. Hyg. (Lond.), 68, 575-580.

Gray, K. G., MacFarlane, D. E., and Sommerville, R. G. (1968). 음 Direct immunofluorescent identification of respiratory syncytial virus in throat swabs from children with respiratory illness. Lancet, 1, 446-448.

Joncas, J. H., Berthiaume, L., Williams, R., Beaudry, P., and Pavilanis, V. (1969). Diagnosis of viral respiratory infections by electron microscopy. Lancet, 1, 956-959.

McQuillin, J., and Gardner, P. S. (1968). Rapid diagnosis of respiratory syncytial virus infection by immunofluorescent antibody음 techniques. Brit. med. J., 1, 602-605.

McQuillin, J., Gardner, P. S., and Sturdy, P. M. (1970). The use of N cough/nasal swabs in the rapid diagnosis of respiratory syncytial virus infection by the fluorescent antibody technique. N J. Hyg. (Lond). 68, 283-292.

Manchester Public Health Laboratory (1964). Further observations on the isolation of viruses from throat swabs by direct inoculation of cell cultures. Mth. Bull. Minist. Hlth Lab. Serv. 23, 136-146.

Sturdy, P. M., McQuillin, J., and Gardner, P. S. (1969). A comparativeC study of methods for the diagnosis of respiratory virus in- $\mathrm{C}$ fections in childhood. J. Hyg. (Lond)., 67, 659-670. 